\title{
Autocrine regulation of human sperm motility by tachykinins
}

\author{
Francisco M Pinto ${ }^{1}$, Cristina G Ravina², Nerea Subiran ${ }^{3}$ Antonio Cejudo-Román ${ }^{1}$, Manuel Fernández-Sánchez² \\ Jon Irazusta ${ }^{3}$, Nicolas Garrido ${ }^{4}$, Luz Candenas ${ }^{1^{*}}$
}

\begin{abstract}
Background: We examined the presence and function of tachykinins and the tachykinin-degrading enzymes neprilysin (NEP) and neprilysin-2 (NEP2) in human spermatozoa.

Methods: Freshly ejaculated semen was collected from forty-eight normozoospermic human donors. We analyzed the expression of substance $P$, neurokinin A, neurokinin $B$, hemokinin-1, NEP and NEP2 in sperm cells by reversetranscriptase polymerase chain reaction (RT-PCR), western blot and immunocytochemistry assays and evaluated the effects of the neprilysin and neprilysin-2 inhibitor phosphoramidon on sperm motility in the absence and presence of tachykinin receptor-selective antagonists. Sperm motility was measured using WHO procedures or computerassisted sperm analysis (CASA).

Results: The mRNAs of the genes that encode substance P/neurokinin A (TAC1), neurokinin B (TAC3), hemokinin-1 (TAC4), neprilysin (MME) and neprilysin-2 (MMEL1) were expressed in human sperm. Immunocytochemistry studies revealed that tachykinin and neprilysin proteins were present in spermatozoa and show specific and differential distributions. Phosphoramidon increased sperm progressive motility and its effects were reduced in the presence of the tachykinin receptor antagonists SR140333 (NK1 receptor-selective) and SR48968 (NK2 receptor-selective) but unmodified in the presence of SR142801 (NK3 receptor-selective).
\end{abstract}

Conclusion: These data show that tachykinins are present in human spermatozoa and participate in the regulation of sperm motility. Tachykinin activity is regulated, at least in part, by neprilysins.

\section{Background}

There is now convincing evidence that tachykinins are involved in the regulation of reproductive function [1-8]. Recent data have demonstrated that tachykinin receptors are present in human sperm and are functionally active suggesting a role for the tachykinin system in the regulation of sperm function [9].

Mammalian tachykinins comprise a family of regulatory peptides including substance $\mathrm{P}(\mathrm{SP})$, neurokinin A (NKA), neurokinin B (NKB) and hemokinin-1 (HK-1) [10-15]. In humans, tachykinins are the products of three different genes. The TAC1 gene gives rise to four different mRNA splicing isoforms $(\alpha, \beta, \gamma$ and $\delta)$ that encode SP $(\alpha, \beta, \gamma$ and $\delta)$ and NKA ( $\beta$ and $\gamma)$. The TAC3 gene encodes NKB. The TAC4 gene can also

\footnotetext{
* Correspondence: luzcandenas@iiq.csic.es

${ }^{1}$ Instituto de Investigaciones Químicas, CSIC, Avda. Americo Vespucio 49, 41092 Sevilla, Spain

Full list of author information is available at the end of the article
}

generate four distinct mRNAs, named $\alpha, \beta, \gamma$ and $\delta$, all of which encode HK-1 $[1,4,11,12]$. Tachykinins effects are mediated by three receptors named $\mathrm{NK}_{1}, \mathrm{NK}_{2}$ and $\mathrm{NK}_{3}$, which, in humans, are encoded by the TACR1, TACR2 and TACR3 genes, respectively [15-19]. The $\mathrm{NK}_{1}$ receptor is activated preferentially by SP and HK-1, the $\mathrm{NK}_{2}$ receptor by NKA, and the $\mathrm{NK}_{3}$ receptor by NKB [15-19].

The neutral endopeptidase EC 3.4.24.11, also named enkephalinase or neprilysin (NEP) is the major peptidase that degrades tachykinins in most human tissues [8,20-23]. NEP also degrades other bioactive peptides such as enkephalins, angiotensins, endothelin-1, cholecystokinins and bradykinin [24-28]. The enzyme is expressed in human sperm [9,25-27] and its inhibition by thiorphan causes a change in sperm motility that is partially mediated by opioids [27]. In addition to classical NEP, a homologous enzyme was recently described and named neprilysin-2 (NEP2) [29]. Human NEP2 has 
much higher substrate specificity and only degrades tachykinins and angiotensin I with efficiency similar to NEP [28]. There are also important differences between enzyme sensitivity to the classical inhibitors, thiorphan and phosphoramidon. Thus thiorphan behaves as a selective NEP inhibitor while phosphoramidon inhibits both enzymes with almost equal potency [24,28]. NEP2 is expressed predominantly in the testis [29-31] and studies in mice deficient in NEP2 have shown that this enzyme is involved in sperm function and oocyte fertilization [31]. However, the role of NEP2 in human reproduction has not jet been established.

In the present study, we investigated the expression and cellular localization of tachykinins and the tachykinin-degrading enzymes NEP and NEP2 in human spermatozoa, analyzed the effects of the NEP and NEP2 inhibitor phosphoramidon on sperm motility, and determined whether endogenous tachykinins are involved in the responses observed after neprilysin inhibition.

\section{Methods}

\section{Chemicals}

SR140333, SR48968 and SR142801 were a generous gift from Sanofi Recherche (Montpellier, France). Phosphoramidon was from Sigma (St. Louis, MO, USA). Drugs were dissolved in distilled water (phosphoramidon) or absolute ethanol (tachykinin receptor antagonists) and diluted into sperm washing medium to appropriate concentrations.

\section{Semen samples and sperm preparation}

Freshly ejaculated semen was collected from forty-eight healthy donors (18-35 years old) after 3-4 days of sexual abstinence. The study was approved by the Ethics Committee of Consejo Superior de Investigaciones Científicas
(CSIC) and all donors gave written informed consent. The samples were allowed to liquefy at $37^{\circ} \mathrm{C}$ for $30 \mathrm{~min}$ and examined for concentration and motility following World Health Organization (WHO) guidelines [32]. Liquefied semen samples were washed with modified human tubal fluid (mHTF, Irvine Scientific, Santa Ana, CA, USA) supplemented with $0.5 \%$ bovine serum albumin (BSA) and processed as previously described [9]. Briefly, sperm suspensions were centrifuged through Spermgrad-125 (Vitrolife, Kungsbacka, Sweden), washed in $\mathrm{mHTF}$, allowed to swim-up for 1 hour at $37^{\circ} \mathrm{C}$ and the supernatant carefully aspirated. Semen motility and concentration were visually re-examined and the concentration adjusted to 50 million per $\mathrm{ml}$ for subsequent experiments.

\section{RNA extraction and reverse transcription-polymerase chain reaction (RT-PCR)}

Total RNA was extracted from sperm pools from 8 different donors using TriReagent (Sigma) and cDNA was synthesized using the Quantitect Reverse Transcription kit (Qiagen, Venlo, The Netherlands). Specific oligonucleotide primer pairs used to amplify $T A C 1, T A C 3$, TAC4, the $\alpha, \beta, \gamma$ and $\delta$ isoforms of TAC1 and TAC4, the genes that encode NEP (MME), NEP2 (MMEL1), $\beta$ actin $(A C T B)$ acrosin $(A C R)$ and $C D 4$ are shown in Table 1 and were synthesized and purified by Sigma Genosys (Cambridge, UK). ACTB served as an internal control while $A C R$ and $C D 4$ were used to verify the presence of sperm cDNA and to exclude the presence of leukocyte contamination, respectively [33-35]. Gene expression was also analyzed in human testis and in a pool of cDNAs from twenty different human tissues (human total RNA master panel, BD Biosciences Clontech, Palo Alto, CA) used as a positive control of amplification.

Table 1 Sequences of forward (F) and reverse (R) primers of indicated target and reference genes

\begin{tabular}{|c|c|c|c|}
\hline Gene & Forward Primer & Reverse Primer & Amplicon size (bp) \\
\hline TAC1 & ACTGTCCGTCGCAAAATCC & ACTGCTGAGGCTTGGGTCTC & 212 \\
\hline$\alpha / \delta T A C 1$ & GGAGCCCTTTGAGCATCTTC & СTITCATAAGCCATTTTGGAGAGA & $168 / 123$ \\
\hline$\beta / \gamma T A C 1$ & GGAGCCCTTTGAGCATCTTC & TTCATAAGCCACAGAATTTAAAGCTC & $220 / 175$ \\
\hline TAC3 & CCAGTGTGTGAGGGGAGCA & TCCAGAGATGAGTGGCTTTTGA & 266 \\
\hline TAC4 & GG TCTCTTCTCTGTGTCTCCTGTCCTC & CATTTATTGAGTGCCTACTGTGTGCT & 246 \\
\hline$\alpha T A C 4 v 1$ & TGTGGCCTTGGAGGAAGG & ACTGCTGCTTGACACTGAGA & 415 \\
\hline$\alpha T A C 4 v 2$ & GCCAAGGAGAAAAAAAGCAT & ACTGCTGCTTGACACTGAGA & 292 \\
\hline$\beta-T A C 4$ & GGAAGCGAGTGGGAGCAT & ACTGCTGCTTGACACTGAGA & 290 \\
\hline$\delta-T A C 4$ & AGTGGGAGGCAGAGAGGAT & ACTGCTGCTTGACACTGAGA & 223 \\
\hline$\gamma-T A C 4$ & AAGGAGAAAAAAAGGCAGAGAG & ACTGCTGCTTGACACTGAGA & 229 \\
\hline MME & AGCCTCTCGGTCCTTGTCCT & GGAGCTGGTCTCGGGAATG & 219 \\
\hline MMEL1 & TGGACATCTTGGAGGTGGTG & GGAGTTCTGGTCGTCGTTCC & 164 \\
\hline ACTB & TCCCTGGAGAAGAGCTACGA & ATCTGCTGGAAGGTGGACAG & 362 \\
\hline$A C R$ & CCCTCCCATTTCGTGTGG & CACAAGTCCAGGTCGATGAGA & 180 \\
\hline$C D 4$ & AGAAAGACGCAAGCCCAGAG & GCACCAGAAGCAAGTGCCTAA & 127 \\
\hline
\end{tabular}


Amplification was performed in PCR buffer containing $3 \mu \mathrm{l}$ of cDNA reaction mixture, $2.5 \mathrm{mM} \mathrm{MgCl}_{2}, 0.2 \mu \mathrm{M}$ primers, $200 \mu \mathrm{M}$ dNTP's and $1.5 \mathrm{U}$ of DNA polymerase (Immolase, Bioline, London, UK). Cycling parameters were: $15 \mathrm{~s}$ at $94^{\circ} \mathrm{C} ; 20 \mathrm{~s}$ at $60^{\circ} \mathrm{C}$ and $20 \mathrm{~s}$ at $72^{\circ} \mathrm{C}$ for 35 cycles. In some experiments, a 1/50 dilution of amplified cDNA was reamplified in the same PCR conditions and with the same primers. The PCR products were separated by gel electrophoresis on $2.5 \%$ agarose. The amplicon sizes were verified by comparison with a DNA size ladder and the identity of the products was established by sequence analysis.

\section{Indirect immunofluorescence}

Sperm cells were washed, resuspended in phosphatebuffered saline (PBS) and smeared onto poly-L-lysinecoated slides. Spermatozoa were fixed in cold methanol $\left(-20^{\circ} \mathrm{C}, 20 \mathrm{~min}\right)$ and incubated with $2 \%$ casein in PBS for $120 \mathrm{~min}$ to block non-specific sites. Test slides were incubated with a primary polyclonal antibody designed to recognize SP (sc-9758, dilution 1:200), NKB (sc14109, dilution 1:200), HK-1 (sc-47439, dilution 1:500), NEP (sc-9149, dilution 1:200) from Santa Cruz Biotechnology (Santa Cruz, CA); NKA (T-4446, dilution 1:400), NKB (T-4450, dilution 1:400) from Peninsula Laboratories Inc. (San Carlos, CA) and NEP2 (HPA 007876, dilution 1:400, recommended by the supplier for immunocytochemistry and sc-104450, dilution 1:100, recommended for western blot) from Sigma and Santa Cruz, respectively. Primary antibodies were incubated overnight at $4^{\circ} \mathrm{C}$ diluted in PBS. The specificity of antibodies was assessed by bibliographic references or by preabsorption with the corresponding immunogenic peptide. Negative control slides were not exposed to the primary antibody and were incubated with a) rabbit or goat IgG or b) PBS and processed in the same conditions as the test slides. Samples were incubated for 60 min with appropriate FITC-conjugated secondary antibodies (Santa Cruz), mounted using Prolong Gold antifade reagent (Invitrogen, Molecular Probes, Eugene, OR) and examined with an Olympus BX-51 fluorescence microscopy (Tokyo, Japan).

\section{Western blot analysis}

Western blotting was used to assess the specificity of NEP and NEP2 antibodies and performed essentially as described previously [9]. Sperm cells were obtained as indicated above. Seminal plasma was obtained by centrifugation of semen samples at $12000 \times g$ for $10 \mathrm{~min}$. Total proteins from semen or seminal plasma samples were extracted by sonication in urea extraction buffer (1\% w/v SDS, 9 M Urea, $1 \mathrm{mM}$ EDTA, $0.7 \mathrm{M}$ mercaptoethanol, in $25 \mathrm{mM}$ Tris- $\mathrm{HCl}, \mathrm{pH} 6.8$ ), boiled for $2 \mathrm{~min}$ and processed by the PAGEprep Advance kit (Pierce, Rockford, IL). Proteins were separated by electrophoresis on $10 \%$ SDS-PAGE gels, transferred to polyvinyldifluoride (PVDF) membranes and processed with the Amersham advance ECL kit (Amersham, Buckinghamshire, UK). Primary antibody dilution was 1:10000 and for the secondary antibody was 1:100000.

\section{Human sperm motility studies}

Motility analysis was performed manually or using a computer-assisted sperm analysis (CASA) system (Sperm Class Analyzer, Microptic, Barcelona, Spain) essentially as described previously $[9,33]$. Aliquots of semen samples $(5 \mu \mathrm{L})$ were placed into a Makler Counting Chamber (Sefi Medical Instruments Ltd., Haifa, Israel) and at least 200 sperm cells were evaluated at each incubation time by phase contrast microscopy. Sperm movement was graded following WHO guidelines [32] and defined as: $a$ : rapid progressive motility; $b$ : slow progressive motility; $c$ : non-progressive motility and $d$ : immotility. Progressive motility $(a+b)$, non-progressive motility $(c)$ and immotility $(d)$ were measured as percentage of the total $(a+b+c+d)$ that was considered as $100 \%$.

Individual sperm samples were divided in several aliquots and each aliquot was untreated (time-matched paired controls) or treated with a single concentration of phosphoramidon ( $1 \mathrm{nM}-1 \mu \mathrm{M})$ or the corresponding solvent. Sperm motility was measured 5 min before agent addition (initial value) and after 1, 15, 60, 120 and 240 min contact time periods. The effect of phosphoramidon $(1 \mu \mathrm{M})$ or its solvent were also investigated in aliquots pretreated for $45 \mathrm{~min}$ with the tachykinin $\mathrm{NK}_{1}$ receptor-selective antagonist SR140333 (10 nM) [36], the $\mathrm{NK}_{2}$ receptor-selective antagonist SR48968 (10 nM) [37], the $\mathrm{NK}_{3}$ receptor-selective antagonist SR142801 (10 nM) [38], a cocktail of the three antagonists (10 nM each) or the corresponding solvent. A maximum of two drug concentrations, or the corresponding solvent volume, were tested on each aliquot. Values of sperm progressive motility, non-progressive motility and immotility were expressed as the positive or negative percentage increment in motility produced by the drug relative to the value observed at the same time in solvent-treated or time-matched paired controls ( $\Delta$ sperm motility).

The effects of phosphoramidon on sperm kinetic parameters were analyzed by CASA, with settings according to instructions by the manufacturer. The measured kinetic parameters were curvilinear velocity (VCL); straight-line velocity (VSL), average path velocity (VAP); percent linearity $(\mathrm{LIN}=\mathrm{VSL} / \mathrm{VCL} \times 100)$ and percent straightness $($ STR $=$ VSL/VAP $\times 100)$. 


\section{Statistical analysis}

Values (means \pm SEM) were obtained by pooling individual data and $n$ indicates the number of experiments in samples from $n$ different donors. Statistical analyses were made using Mann-Whitney's $U$ (for comparison of mean ranks between two groups) or Kruskal-Wallis (to compare more than two groups) nonparametric tests. These procedures were undertaken using GRAPHPAD PRISM (version 5.0). $P<0.05$ values were considered significant.

\section{Results}

mRNA expression of tachykinins and neprilysins in human sperm

The genes that encode SP/NKA (TAC1), NKB (TAC3), hHK-1(TAC4), NEP (MME) and NEP2 (MMEL1) were detected in cDNAs from human sperm, testis and the pool of 20 human tissues used as positive control (Fig. 1). In sperm, the mRNAs of TAC4 and $M M E$ were only visualized after cDNA reamplification. Using specific primers and cDNA reamplification, we observed that, among the TAC1 isoforms, only the $\gamma$ and $\delta$ transcripts were detectable in human spermatozoa (Fig. 1). TAC1- $\beta$, $T A C 1-\gamma$ and $T A C 1-\delta$ were expressed in human testis, the last one being only observed after cDNA reamplification. Splice variants of the TAC4 gene were present in the positive control but were undetected in testis and sperm cDNAs (data not shown). We also verified the presence of $A C T B$ and $A C R$ and the absence of $C D 4$ mRNA in all sperm samples (Fig. 1, not shown for $A C T B$ ).

Three negative controls were included in all assays (no reverse transcriptase, no RNA in the reverse transcriptase reaction and no template) and no PCR product was detected in any of these controls.

\section{Immunodetection of tachykinins and neprilysins in human sperm}

Immunocytochemistry demonstrated positive immunostaining for tachykinins, NEP and NEP2 in sperm cells (Figs. 2, 3 and 4). Intense SP labeling was observed over the acrosomal region and around the connecting piece in approximately $80 \%$ of the cells. In the other cells, SP

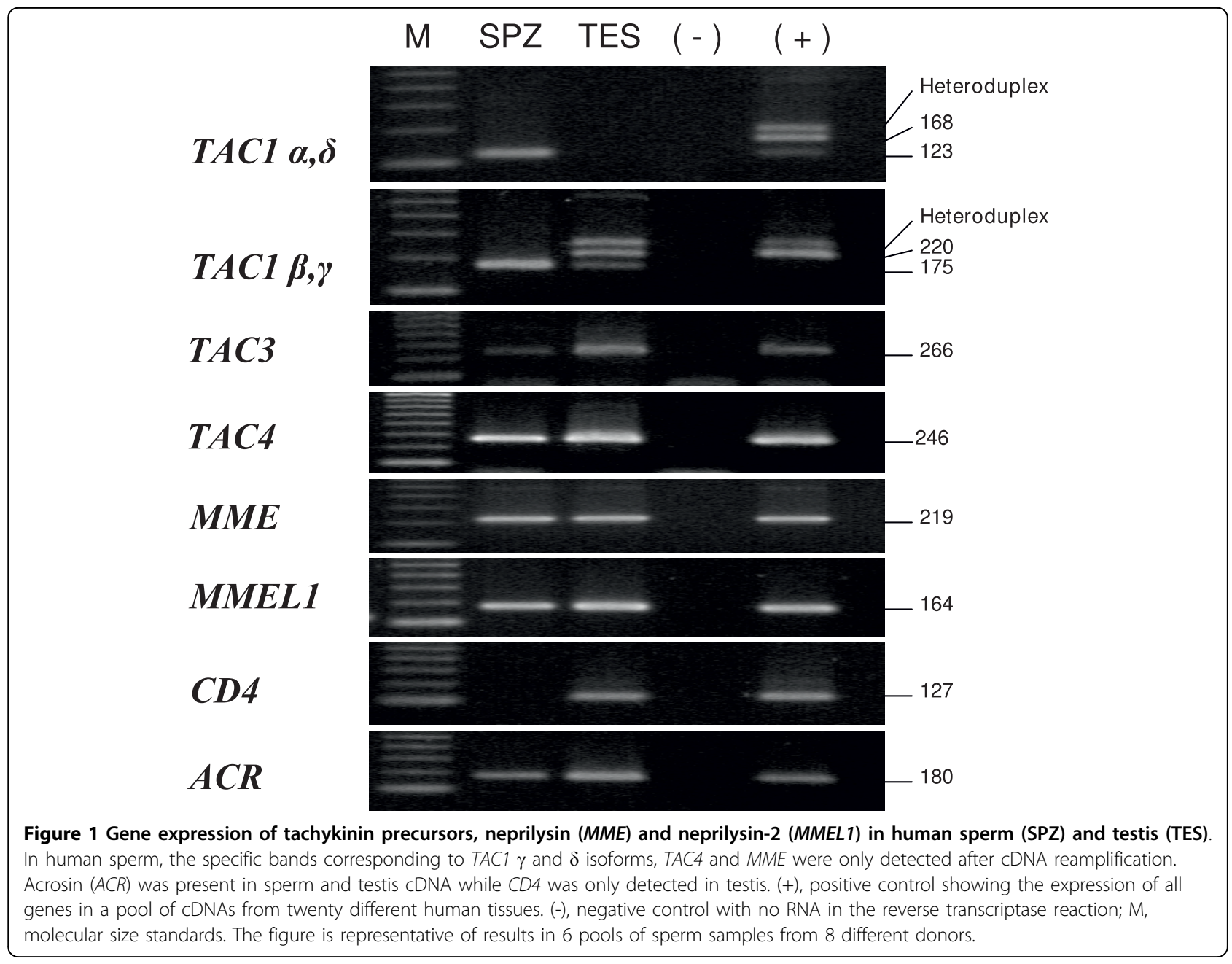




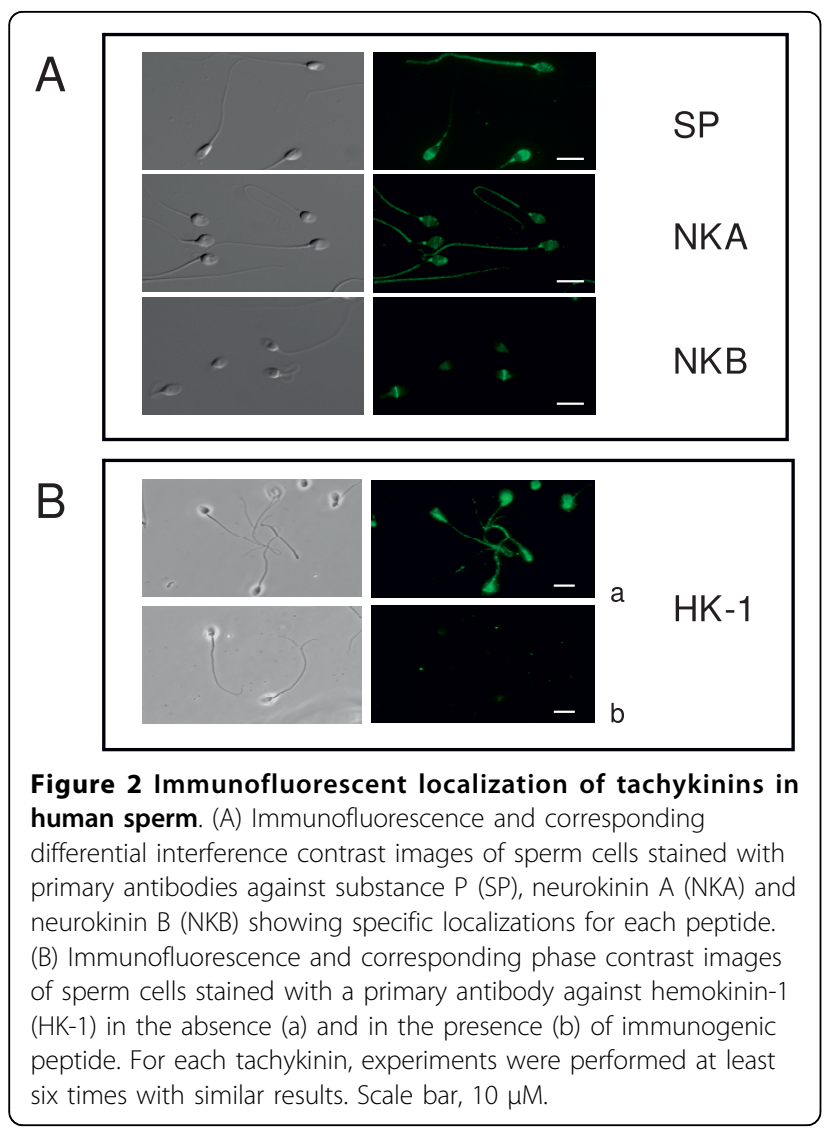

immunostaining was only observed around the connecting piece and the flagellum principal piece (Fig. 2A). NKA was mainly found around the neck with a less intense immunostaining of the sperm head and the flagellum principal piece. NKB immunofluorescence was restricted to the equatorial segment and the post-equatorial region of the head (Fig. 2A). We found identical NKB immunolocalization with two different antibodies. HK-1 was present in the postacrosomal region and along the tail and intense labeling was detected in the flagellum midpiece being the only tachykinin that was present in this sperm area (Fig. 2B). Preincubation of the primary antiserum with SP or HK-1 immunogenic peptide $(5 \mu \mathrm{g} / \mathrm{ml})$ caused a disappearance of the fluorescent signal (Fig. 2B, not shown for SP). NEP immunostaining was localized in the equatorial segment in approximately $80 \%$ of cells, detected around the neck in a small, different population of sperm cells (approximately 3\%) or undetectable (Fig. 3A). NEP2 was localized around the equatorial segment and the postacrosomal region of spermatozoa with the HPA 007876 antibody (Fig. 3A). Unspecific binding was not observed in the presence of preimmune rabbit or goat serum and there was no immunofluorescence in the absence of the corresponding primary antibody.

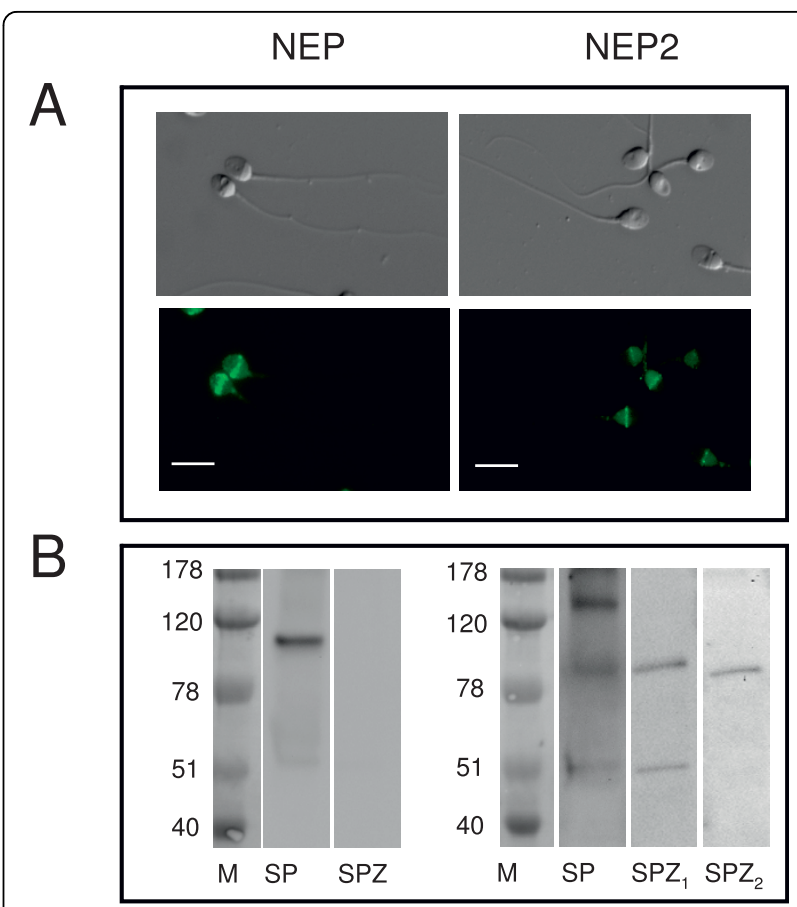

Figure 3 Localization of neprilysins in human sperm. (A) Immunofluorescence and corresponding differential interference contrast images of sperm cells stained with primary antibodies against neprilysin (NEP) and neprilysin-2 (NEP2). Experiments were performed at least six times with similar results. Scale bar, $10 \mu \mathrm{M}$. (B) Western Blot analysis of NEP and NEP2 in human spermatozoa (SPZ) and seminal plasma (SP) homogenates. For NEP2, SP and SPZ1 represent results obtained with the NEP2 antibody Sc-104450 and $\mathrm{SPZ}_{2}$ represents results obtained with the NEP2 antibody HPA 007876 (see text for further details). Results are representative of at least five separate protein preparations, each from eight different donors.

Western blot confirmed the specificity of NEP and NEP2 antibodies and showed the presence of both enzymes in seminal plasma and of NEP2 in spermatozoa. The NEP antibody labeled a band of approximately $100 \mathrm{kDa}$ (Fig. 3B). In agreement with previous data [27] the NEP signal was not observed in sperm. The NEP2 antibody HPA 007876, used in immunocytochemistry studies, recognized a band of approximately $90 \mathrm{kDa}$, the size expected for the major membrane-bound human NEP2 isoform [32]. As a positive control, we used a second human NEP2 antibody, sc-104450, recommended by the supplier for western blot. This second NEP2 antibody labeled the $90 \mathrm{kDa}$ band in both spermatozoa and seminal plasma (Fig. 3B). In seminal plasma it recognized a second band, of approximately $130 \mathrm{kDa}$, which may correspond to an already described, additional membrane-associated isoform or to the soluble form of human NEP2 [32]. A third unknown band of approximately $50 \mathrm{kDa}$ was detected with the sc- 104450 antibody in seminal plasma and sperm cells. The 
immunoreactive bands for NEP and NEP2 were not observed when primary antibodies were omitted (data not shown).

\section{Effects of phosphoramidon on human sperm motility}

The NEP and NEP2 inhibitor phosphoramidon caused time- and concentration-dependent increases in the proportion of progressively motile sperm (Fig. 4). The magnitude of the effect of phosphoramidon was inversely related to the initial proportion of progressive motile sperm in the sample. Thus, in samples with initial values of sperm progressive motility of $45-60 \%$, the percentage of grade $a+b$ sperm was $64.8 \pm 3.8$ in samples treated with $1 \mu \mathrm{M}$ phosphoramidon for $60 \mathrm{~min}$ and $51.0 \pm 3.2$ in time-matched paired aliquots $(P<0.05)$. Sperm progressive motility was not affected by the phosphoramidon solvent $(50.0 \pm 3.3, P>0.05$ vs. time-matched controls). The results were similar when sperm motility was measured manually (Fig. 4A, B) or by CASA (Fig. $4 C)$. The use of CASA revealed that phosphoramidon increased particularly the percentage of grade $a$ spermatozoa (Fig. 4C). With regard to sperm kinetimatic parameters, CASA analysis showed that phosphoramidon increased straightness (by $6.13 \pm 1.74 \%$ ) and linearity (by $7.56 \pm 0.98 \%)(P<0.05 v s$. solvent-treated aliquots) leading to a motility pattern characteristic of non-hyperactivated sperm.

We then analyzed whether tachykinin receptors could mediate the actions of phosphoramidon on sperm motility. The effect of phosphoramidon $(1 \mu \mathrm{M}, 60 \mathrm{~min}$ incubation) was reduced by preincubation of the sperm sample for $45 \mathrm{~min}$ with the $\mathrm{NK}_{1}$ receptor-selective antagonist SR140333 (10 nM) or the $\mathrm{NK}_{2}$ receptorselective antagonist SR48968 (10 nM) but was not affected by the $\mathrm{NK}_{3}$ receptor-selective antagonist SR142801 (10 nM) (Fig. 5). The phosphoramidoninduced effect was reduced, but not abolished, in the presence of a combination of the three tachykinin receptor antagonists (each at a concentration of $10 \mathrm{nM}$, Fig $5)$. The antagonist solvent had no effect on phosphoramidon responses (Fig 5).

\section{Discussion}

In the present study, the major findings are: a) the tachykinin peptides, SP, NKA, NKB and HK-1 are present in human sperm; b) the two most important enzymes involved in tachykinin metabolism, NEP and NEP2 are expressed in human spermatozoa and c) the endogenous tachykinins modulate the motility of these cells.

The mRNAs of TAC1, TAC3 and TAC4, coding for the human tachykinin peptides, were expressed in sperm (9, this study). Among the TAC1 isoforms, only $T A C 1-\gamma$ and the rare $T A C 1-\delta$ were present in spermatozoa. Conversely, the $\alpha$ and $\beta$ isoforms were absent, in spite of the fact that $T A C 1-\beta$ is one of the most abundant TAC1 isoforms in many human cells and tissues including the testis $[2,6,14]$. With respect to TAC4, none of its splicing variants was detected. Increasing evidence suggests that the specific fraction of mRNAs that stays in mature spermatozoa plays some role in subsequent fertilization steps or is required for adequate embryo formation [39-42]. In this context, recent reports have established the existence of important differences between the sperm transcriptome of fertile and infertile men [42] providing clinical support for the relevance of sperm mRNA in male fertility.

The mRNAs of all tachykinins were present in human testis and sperm. Because spermatozoa are considered transcriptionally silent cells, the presence of these mRNA unequivocally proves that the genes encoding these proteins are transcribed in germ cells at any step during spermatogenesis. In addition, immunocytochemistry studies revealed that all tachykinin peptides were present in mature spermatozoa. Major labeling was observed over the acrosomal region for SP, around the connecting piece for NKA, in the equatorial/post-acrosomal region for $\mathrm{NKB}$ and around the midpiece for HK-1. This regional pattern of distribution argues for a specific role for each tachykinin in the regulation of sperm function. The presence of NKB in the equatorial segment suggests that this tachykinin could be involved in the fertilization process because this segment appears important in the fusion of gametes [43]. It has recently been shown that the $\mathrm{NKB} / \mathrm{NK}_{3}$ ligand-receptor pair plays a central role in the regulation of reproductive functions [4-9]. In this context, it is interesting to note that NKB immunostaining was in a similar location than that previously found for the tachykinin $\mathrm{NK}_{3}$ receptor [9].

The local bioactivity of peptide signaling molecules is tightly controlled by their enzymatic degradation. Our data show that NEP and NEP2, the most important enzymes involved in tachykinin metabolism, are expressed in human sperm at both mRNA and protein levels. In reference to NEP, the data confirm previous results showing the expression of this enzyme in sperm [25-27]. With respect to NEP2, we report for the first time the presence of this enzyme in human spermatozoa. The observation that NEP2 was placed around the equatorial segment of human spermatozoa support a role for this enzyme in sperm fertilizing ability. These data are in line with previous findings showing that sperm from NEP2 knockout mice show apparently normal characteristics but lower oocyte fertilization and reduced embryo development [31].

NEP and NEP2 were abundant in seminal plasma suggesting that the activity of their substrates must be 


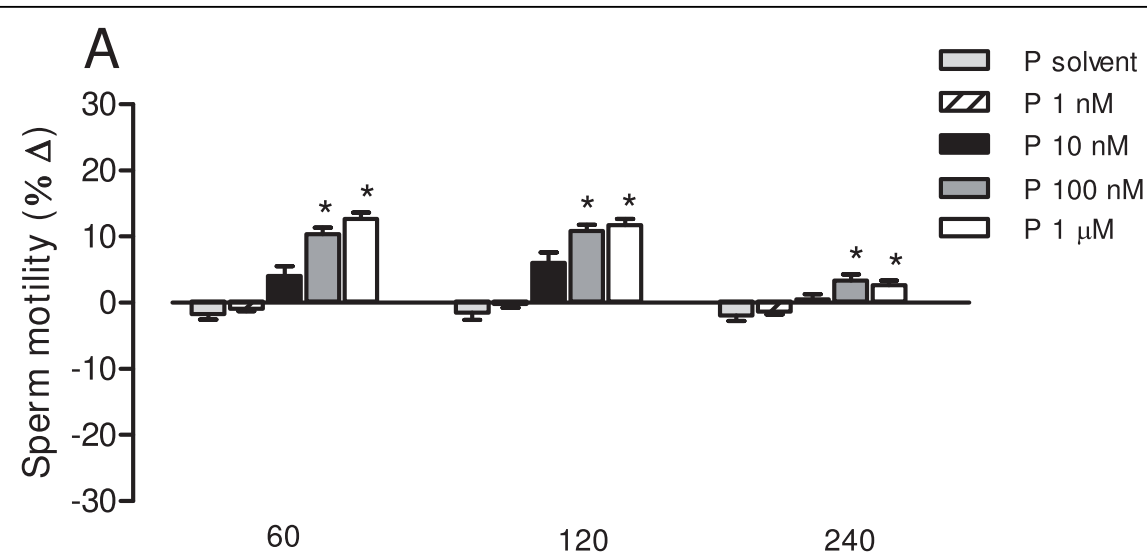

Time (min)

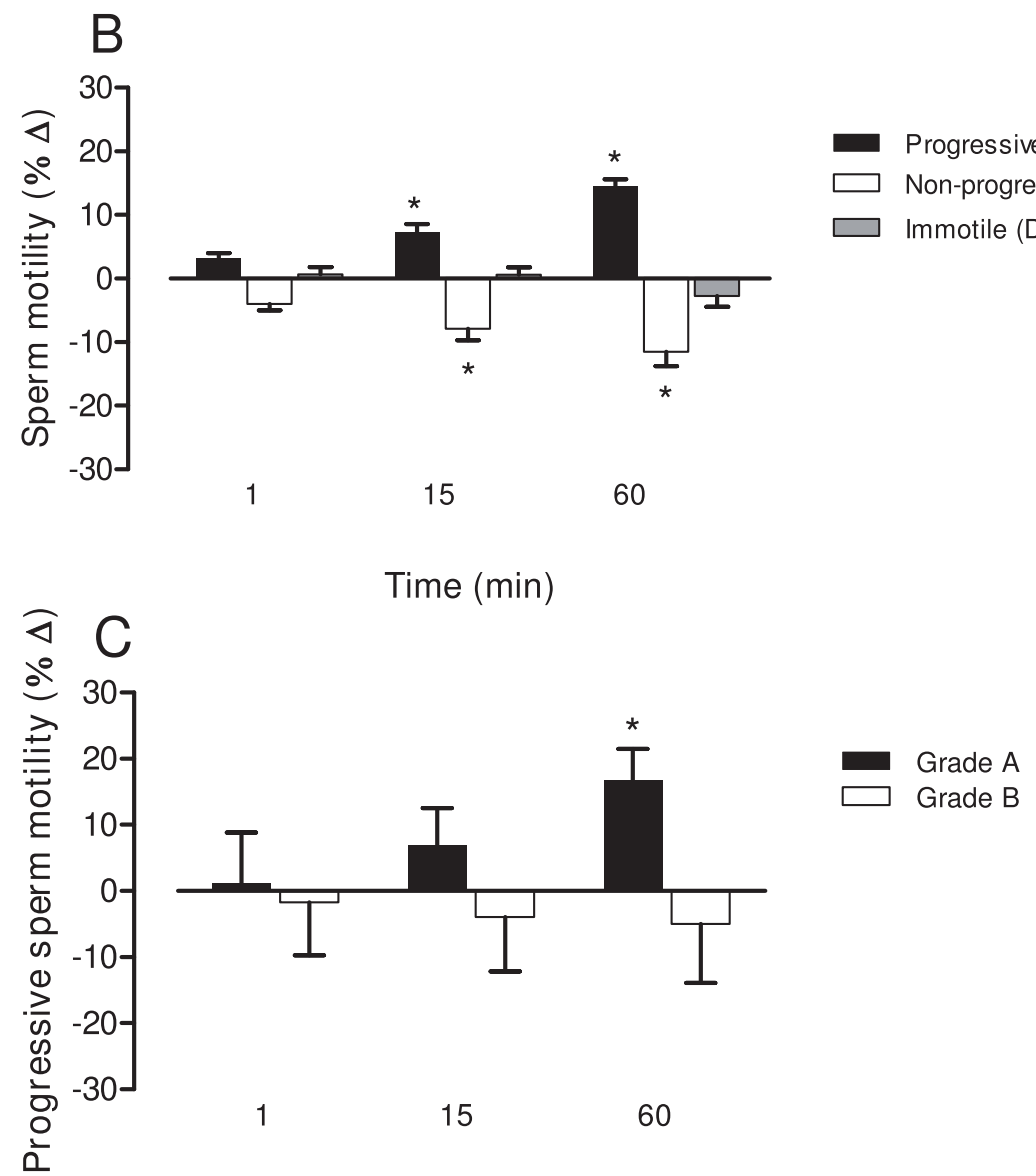

Time $(\min )$

Figure 4 Time- and concentration-dependent effects of phosphoramidon on human sperm motility. Motility analysis was performed manually (A, B) or using a computer-assisted sperm analysis (CASA) system (C). (A) Effects of phosphoramidon (1 nM-1 $\mu \mathrm{M})$ or its solvent on progressive motility (grade $a+b$ sperm) at different times of incubation (B) Effects of phosphoramidon ( $1 \mu \mathrm{M})$ on progressive motility (grade $a+b$ sperm), non-progressive motility (grade $c$ sperm) and immotility (grade $d$ sperm) at different times of incubation. (C) Effects of phosphoramidon $(1 \mu \mathrm{M})$ on grade $a$ and grade $b$ sperm at different times of incubation. Bars are means with SEM of 6-13 different experiments and represent percentage changes in motility in samples treated with phosphoramidon relative to the value observed at the same time in untreated (A) or solvent-treated $(B, C)$ paired controls. ${ }^{*} P<0.05$, significant difference vs. control responses. 


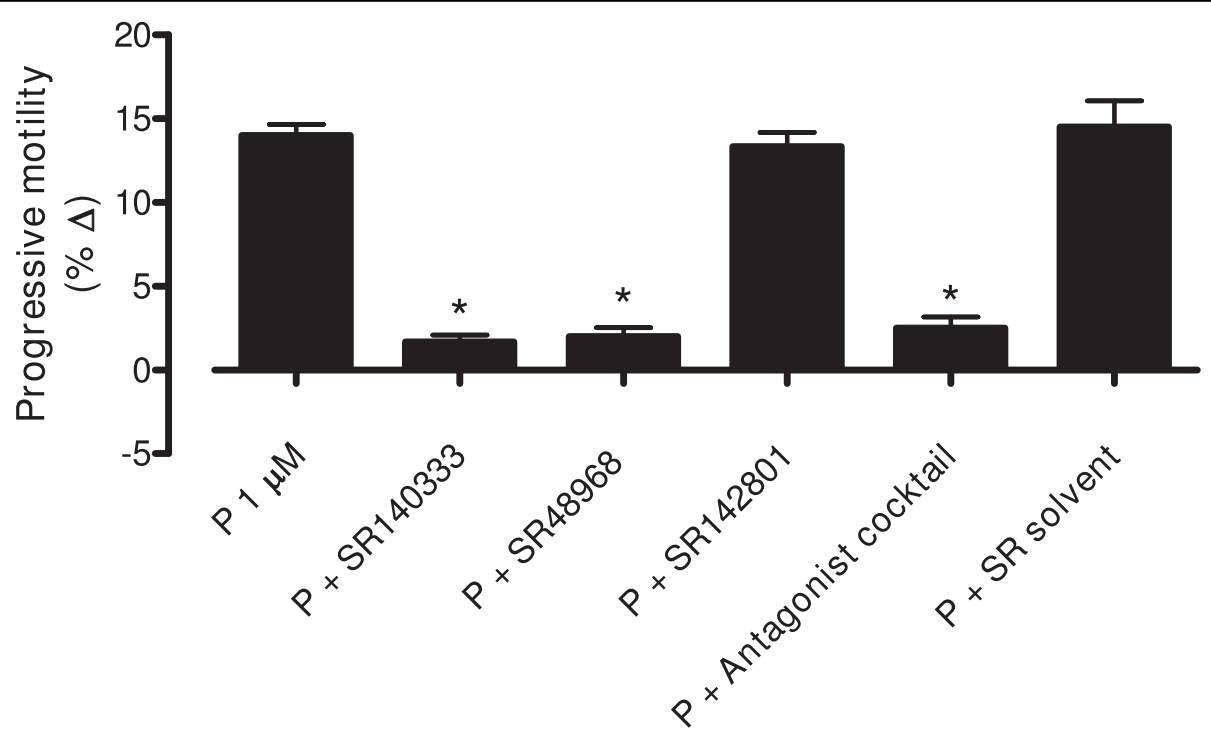

Figure 5 Tachykinin receptor-selective antagonists inhibit the effect of phosphoramidon on sperm motility. The effects of phosphoramidon ( $1 \mu \mathrm{M}, 60 \mathrm{~min}$ incubation) on human sperm progressive motility (grade $a+b$ sperm) were analyzed in the presence of SR140333 ( $\mathrm{NK}_{1}$ antagonist, $10 \mathrm{nM}$ ), SR48968 (NK ${ }_{2}$ antagonist, $10 \mathrm{nM}$ ), SR142801 ( $\mathrm{NK}_{3}$ antagonist, $10 \mathrm{nM}$ ), a combination of the three antagonists, or the antagonist solvent. Motility analysis was performed manually following WHO guidelines. Bars are means with SEM of 6-8 different experiments and represent percentage changes in motility in samples treated with phosphoramidon relative to the value observed at the same time in phosphoramidon solvent-treated paired controls. ${ }^{*} P<0.05$, significant difference vs. response to phosphoramidon.

strictly controlled during the last maturation steps in the male reproductive tract and/or during ejaculation. In mature spermatozoa, inhibition of both enzymes by phosphoramidon caused an increase in sperm progressive motility. Sperm motility is an important feature and the most reliable actual predictor of male factor infertility $[44,45]$. Our data show that phosphoramidon induced a rise in straightness and linearity leading to motility trajectories that are characteristics of non hyperactivated spermatozoa and this is important because only spermatozoa with good progressive motility are able to swim through the female reproductive tract and reach the oviduct.

The responses elicited by phosphoramidon were reduced in the presence of SR140333, a selective antagonist of the tachykinin $\mathrm{NK}_{1}$ receptor [36], and in the presence of SR48968, a selective antagonist of the tachykinin $\mathrm{NK}_{2}$ receptor [37]. This demonstrates that the effects observed after neprilysin inhibition are mediated, at least in part, by tachykinins acting at the $\mathrm{NK}_{1}$ and the $\mathrm{NK}_{2}$ receptor. Conversely, the effects of phosphoramidon were unaffected in the presence of SR142801, a selective antagonist of the tachykinin $\mathrm{NK}_{3}$ receptor [38], consistent with our previous data which showed that the $\mathrm{NK}_{3}$ receptor plays a minor role in mediating motility changes induced by exogenously applied tachykinins in human sperm [9].

The effects of phosphoramidon were reduced, but not abolished, in the presence of a combination of
SR140333, SR48968 and SR142801. NEP and NEP2 participate in degradation of other peptides, such as angiotensin-1, bradykinin and enkephalins which are also implicated in sperm cell function $[27,28]$ and might thus be relevant to explain the tachykinin antagonist-resistant component of the response to phosphoramidon. In fact, the NEP inhibitor thiorphan increased sperm progressive motility and the opioid receptor antagonist naloxone inhibited the effects observed after prolonged $(4 \mathrm{~h})$ but not shorter $(2 \mathrm{~h})$ periods of incubation with thiorphan [27]. It thus seems that both tachykinins and opioids are involved in the responses observed after neprilysin inhibition in human sperm without ruling out the possible involvement of other peptide substrates.

Bioactive peptides i.e., opioids [27], bradykinin [28] or tachykinins [[9], this study] are widely expressed in sperm and many of the enzymes involved in their metabolism are also present and are functionally active $[25,27,28]$. Inhibition of these enzymes caused slowly developing changes in sperm motility $[[27,28]$, this study]. Thus, these biopeptides, and particularly tachykinins, could operate as signal molecules between spermatozoa and their environment acting in an autocrine and/ or paracrine (effect on other cells, on the female genital tract, and viceversa) fashion. In fact, $\mathrm{NK}_{1} \mathrm{NK}_{2}$ and $\mathrm{NK}_{3}$ receptors are present in sperm and exogenously applied tachykinins modulate progressive motility at nanomolar concentrations [9]. Further studies will help to clarify the precise role of neprilysins and neprylisin-sensitive 
peptides in the regulation of sperm physiology and male fertility.

\section{Conclusions}

The present study shows that tachykinins and the tachykinin-degrading enzymes NEP and NEP2 are present in human spermatozoa and participate in the regulation of sperm motility. These data support a role for the tachykinin system in the regulation of sperm function.

\section{Abbreviations \\ SP: substance P; NKA: neurokinin A; NKB: neurokinin B; HK-1: hemokinin-1; NEP: neprilysin; NEP2: neprilysin-2; BSA: bovine serum albumin; RT-PCR: reverse-transcriptase polymerase chain reaction; CASA: computer-assisted sperm analysis; WHO: World Health Organization; MHTF: modified human tubal fluid; PBS: phosphate-buffered saline.}

\section{Acknowledgements}

This work was supported by grants from Junta de Andalucía (P08-CVI-04185) and Ministerio de Educación y Ciencia (CTQ2007-61024/BQU), Spain. A. Cejudo-Román is supported by Junta de Andalucia, Spain.

\section{Author details}

${ }^{1}$ Instituto de Investigaciones Químicas, CSIC, Avda. Americo Vespucio 49, 41092 Sevilla, Spain. ${ }^{2}$ Instituto Valenciano de Infertilidad de Sevilla, Avenida Republica Argentina 58, 41011 Sevilla, Spain. ${ }^{3}$ Department of Physiology, Faculty of Medicine and Dentistry, University of the Basque Country, 48940 Leioa, Bizkaia, Spain. ${ }^{4}$ Instituto Valenciano de Infertilidad de Valencia, Plaza de la Policía Local 3, 46015 Valencia, Spain.

\section{Authors' contributions}

FMP carried out RT-PCR, western blot analysis and participated in the design of the study. NS and ACR carried out motility studies and immunofluorescence experiments. CGR and MFS participated in sample collection and analysis of sperm parameters. NG, $\mathrm{J}$ and LC wrote the manuscript and participated in the design of the study. All authors read and approved the final manuscript.

\section{Competing interests}

The authors declare that they have no competing interests.

Received: 14 May 2010 Accepted: 26 August 2010

Published: 26 August 2010

\section{References}

1. Brown ER, Harlan RE, Krause JE: Gonadal steroid regulation of substance $P$ (SP) and SP-encoding messenger ribonucleic acids in the rat anterior pituitary and hypothalamus. Endocrinology 1990, 126:330-340.

2. Chiwakata C, Brackmann B, Hunt N, Davidoff M, Schulze W, Ivell R: Tachykinin (substance-P) gene expression in Leydig cells of the human and mouse testis. Endocrinology 1991, 128:2441-2448.

3. Pinto FM, Armesto CP, Magraner J, Trujillo M, Martín JD, Candenas ML: Tachykinin receptor and neutral endopeptidase gene expression in the rat uterus: characterization and regulation in response to ovarian steroid treatment. Endocrinology 1999, 140:2526-2532.

4. Page NM: Neurokinin B and pre-eclampsia: a decade of discovery. Reprod Biol Endocrinol 2010, 8:4.

5. Debeljuk L, Rao JN, Bartke A: Tachykinins and their possible modulatory role on testicular function: a review. Int J Androl 2003, 26:202-210.

6. Pintado CO, Pinto FM, Pennefather JN, Hidalgo A, Baamonde A, Sanchez T, Candenas ML: A role for tachykinins in female mouse and rat reproductive function. Biol Reprod 2003, 69:940-946.

7. Topaloglu AK, Reimann F, Guclu M, Yalin AS, Kotan LD, Porter KM, Serin A, Mungan NO, Cook JR, Ozbek MN, Imamoglu S, Akalin NS, Yuksel B, O'Rahilly S, Semple RK: TAC3 and TACR3 mutations in familial hypogonadotropic hypogonadism reveal a key role for Neurokinin B in the central control of reproduction. Nature Genet 2009, 41:354-358.
8. Pennefather JN, Patak E, Pinto FM, Candenas ML: Mammalian tachykinins and uterine smooth muscle: the challenge escalates. Eur J Pharmacol 2004, 500:15-26.

9. Ravina CG, Seda M, Pinto FM, Orea A, Fernandez-Sanchez M, Pintado CO, Candenas ML: A role for tachykinins in the regulation of human sperm motility. Hum Reprod 2007, 22:1617-1625.

10. Patacchini R, Lecci A, Holzer P, Maggi CA: Newly discovered tachykinins raise new questions about their peripheral roles and the tachykinin nomenclature. Trends Pharmacol Sci 2004, 25:1-3.

11. Page NM: Hemokinins and endokinins. Cell Mol Life Sci 2004, 61:1652-1663.

12. Zhang $Y$, Berger $A$, Milne $C D$, Paige $C J$ : Tachykinins in the immune system. Curr Drug Targets 2006, 7:1011-1020.

13. Greco SJ, Corcoran KE, Cho KJ, Rameshwar P: Tachykinins in the emerging immune system: relevance to bone marrow homeostasis and maintenance of hematopoietic stem cells. Front Biosci 2004, 9:1782-1793.

14. Lai J-P, Douglas SD, Zhao M, Ho W-Z: Quantification of substance P mRNA in human mononuclear phagocytes and lymphocytes using a mimicbased RT-PCR. J Immunol Meth 1999, 230:149-157.

15. Almeida TA, Rojo J, Nieto PM, Pinto FM, Hernandez M, Martin JD, Candenas ML: Tachykinins and tachykinin receptors: structure and activity relationships. Curr Med Chem 2004, 11:2045-2081.

16. Nakanishi S: Mammalian tachykinin receptors. Annu Rev Neurosci 1991 14:123-136.

17. Gerard NP, Bao L, Xiao-Ping H, Gerard C: Molecular aspects of the tachykinin receptors. Regul Pept 1993, 43:21-35.

18. Tuluc F, Lai JP, Kilpatrick LE, Evans DL, Douglas SD: Neurokinin 1 receptor isoforms and the control of innate immunity. Trends Immunol 2009, 30:271-276.

19. Lecci A, Maggi CA: Peripheral tachykinin receptors as potential therapeutic targets in visceral diseases. Expert Opin Ther Targets 2003, 7:343-362.

20. Malfroy B, Kuang WJ, Seeburg PH, Mason AJ, Schofield PR: Molecular cloning and amino acid sequence of human enkephalinase (neutral endopeptidase). FEBS Lett 1988, 229:206-210.

21. Turner AJ, Isaac RE, Coates D: The neprilysin (NEP) family of zinc metalloendopeptidases: genomics and function. Bioessays 2001, 23:261-269.

22. Hooper NM, Kenny AJ, Turner AJ: The metabolism of neuropeptides. Neurokinin A (substance K) is a substrate for endopeptidase-24.11 but not for peptidyl dipeptidase A (angiotensin-converting enzyme). Biochem J 1985, 231:357-361.

23. Hooper NM, Turner AJ: Neurokinin B is hydrolysed by synaptic membranes and by endopeptidase-24.11 (enkephalinase) but not by angiotensin converting enzyme. FEBS Lett 1985, 190:133-136.

24. Rose C, Voisin S, Gros C, Schwartz JC, Ouimet T: Cell-specific activity of neprilysin 2 isoforms and enzymic specificity compared with neprilysin. Biochem J 2002, 363:697-705.

25. Fernández D, Valdivia A, Irazusta J, Ochoa C, Casis L: Peptidase activities in human semen. Peptides 2002, 23:461-468

26. Siems WE, Maul B, Wiesner B, Becker $M$, Walther $T$, Rothe $L$, Winkler $A$ : Effects of kinins on mammalian spermatozoa and the impact of peptidolytic enzymes. Andrologia 2003, 35:44-54.

27. Subirán N, Agirregoitia E, Valdivia A, Ochoa C, Casis L, Irazusta J: Expression of enkephalin-degrading enzymes in human semen and implications for sperm motility. Fertil Steril 2008, 89:1571-1577.

28. Whyteside AR, Turner AJ: Human neprilysin-2 (NEP2) and NEP display distinct subcellular localisations and substrate preferences. FEBS Lett 2008, 582:2382-2386.

29. Ghaddar G, Ruchon AF, Carpentier M, Marcinkiewicz M, Seidah NG, Crine $P$, Desgroseillers L, Boileau G: Molecular cloning and biochemical characterization of a new mouse testis soluble-zinc-metallopeptidase of the neprilysin family. Biochem J 2000, 347:419-429.

30. Bonvouloir N, Lemieux N, Crine P, Boileau G, DesGroseillers L: Molecular cloning, tissue distribution, and chromosomal localization of MMEL2, a gene coding for a novel human member of the neutral endopeptidase24.11 family. DNA Cell Biol 2001, 20:493-498.

31. Carpentier M, Guillemette C, Bailey JL, Boileau G, Jeannotte L, DesGroseillers L, Charron J: Reduced fertility in male mice deficient in the zinc metallopeptidase NL1. Mol Cell Biol 2004, 24:4428-4437. 
32. World Health Organization: WHO laboratory Manual for the examination of human semen and sperm-cervical mucus interaction Cambridge: Cambridge University Press 1999.

33. Pinto FM, Ravina CG, Fernández-Sánchez M, Gallardo-Castro M, CejudoRomán A, Candenas L: Molecular and functional characterization of voltage-gated sodium channels in human sperm. Reprod Biol Endocrinol 2009, 7:71.

34. Zuccarello D, Garolla A, Ferlin A, Menegazzo M, De Toni L, Carraro M, Veronese C, Foresta C: Androgen receptor is expressed in both X- and Ycarrier human spermatozoa. Fertil Steril 2009, 91:193-200.

35. Agirregoitia E, Carracedo A, Subirán N, Valdivia A, Agirregoitia N, Peralta L, Velasco G, Irazusta J: The $\mathrm{CB}(2)$ cannabinoid receptor regulates human sperm cell motility. Fertil Steril 2009.

36. Emonds-Alt X, Doutremepuich JD, Heaulme M, Neliat G, Santucci V, Steinberg R, Vilain P, Bichon D, Ducoux JP, Proietto V: In vitro and in vivo biological activities of SR 140333, a novel potent non-peptide tachykinin $\mathrm{NK}_{1}$ receptor antagonist. Eur J Pharmacol 1993, 250:403-413.

37. Emonds-Alt $X$, Vilain $P$, Goulaouic $P$, Proietto V, Van Broeck D, Advenier $C$ Naline E, Neliat G, Le Fur G, Breliere JC: A potent and selective nonpeptide antagonist of the neurokinin A (NK2) receptor. Life Sci 1992, 50: L101-L106.

38. Emonds-Alt X, Bichon D, Ducoux JP, Heaulme M, Miloux B, Poncelet M, Proietto V, Van Broeck D, Vilain P, Neliat G: SR 142801, the first potent non-peptide antagonist of the tachykinin $\mathrm{NK}_{3}$ receptor. Life Sci 1995, 56 L27-L32.

39. Ostermeier GC, Dix DJ, Miller D, Khatri P, Krawetz SA: Spermatozoal RNA profiles of normal fertile men. Lancet 2002, 360:772-777.

40. Miller D, Ostermeier GC, Krawetz SA: The controversy, potential and roles of spermatozoal RNA. Trends Mol Med 2005, 11:156-163.

41. Boerke A, Dieleman SJ, Gadella BM: A possible role for sperm RNA in early embryo development. Theriogenology 2007, 68:S147-S155.

42. García-Herrero S, Meseguer M, Martínez-Conejero JA, Remohí J, Pellicer A, Garrido N: The transcriptome of spermatozoa used in homologous intrauterine insemination varies considerably between samples that achieve pregnancy and those that do not. Fertil Steril 2009.

43. Flesch FM, Gadella BM: Dynamics of the mammalian sperm plasma membrane in the process of fertilization. Biochim Biophys Acta 2000, 1469:197-235

44. Mahfouz R, Sharma R, Thiyagarajan A, Kale V, Gupta S, Sabanegh E, Agarwal A: Semen characteristics and sperm DNA fragmentation in infertile men with low and high levels of seminal reactive oxygen species. Fertil Steril 2010.

45. Coy P, Lloyd R, Romar R, Satake N, Matas C, Gadea J, Holt WV: Effects of porcine pre-ovulatory oviductal fluid on boar sperm function. Theriogenology 2010.

doi:10.1186/1477-7827-8-104

Cite this article as: Pinto et al: Autocrine regulation of human sperm motility by tachykinins. Reproductive Biology and Endocrinology 2010 8:104.

\section{Submit your next manuscript to BioMed Central and take full advantage of:}

- Convenient online submission

- Thorough peer review

- No space constraints or color figure charges

- Immediate publication on acceptance

- Inclusion in PubMed, CAS, Scopus and Google Scholar

- Research which is freely available for redistribution 